\title{
One-pot, three-component synthesis of highly substituted pyridines and 1,4-dihydropyridines by using nanocrystalline magnesium oxide
}

\author{
M LAKSHMI KANTAM ${ }^{1, *}$, KOOSAM MAHENDAR $^{1}$ and SURESH BHARGAVA ${ }^{2}$ \\ ${ }^{1}$ Inorganic and Physical Chemistry Division, Indian Institute of Chemical Technology, \\ Hyderabad 500007 \\ ${ }^{2}$ School of Applied Sciences, RMIT University, Melbourne, Australia \\ e-mail: mlakshmi@iict.res.in
}

\begin{abstract}
One pot, three component synthesis of 2-amino-4-aryl-3,5-dicyano-6-sulfanylpyridines and the corresponding 1,4-dihydropyridines are from readily accessible starting materials is described. Simply heating of an ethanolic solution of structurally diverse aldehydes with various thiols and malononitrile in the presence of nanocrystalline magnesium oxide provides the highly substituted pyridine derivatives in moderate to high yields, each representing a privileged medicinal scaffold with their structural motif. After completion of the reaction, the catalyst can be recovered efficiently and reused with constintent activity.
\end{abstract}

Keywords. Multicomponent reactions (MCRs); pyridines; 1,4-dihydropyridines; aldehydes; thiols; malononitrile; nanocrystalline magnesium oxide.

\section{Introduction}

One-pot multicomponent coupling reactions (MCRs), where several organic moieties are coupled in one step, for carbon-carbon and carbon-heteroatom bond formation is an attractive synthetic strategy for the synthesis of small-molecule libraries with several degrees of structural diversities. ${ }^{1}$ The pyridine moiety has been found in a wide variety of both naturally occurring and synthetic bioactive compounds, and are often with considerable complexity. ${ }^{2}$ The highly substituted pyridine derivatives, like 2-amino-4-aryl3,5-dicyano-6-sulfanylpyridines have significant and diverse medicinal utility. Essentially, these compounds serve as high-potency agonists for the human adenosine receptors and act as potential therapeutic agents for the treatment of Creutzfeldt-Jacob disease, Parkinson's disease, hypoxia, asthma, cancer, kidney disease and prion disease. ${ }^{3}$ In addition, they serve as potassium channel openers with applications in treating urinary incontinence and exhibit anti-bacterial, anti-biofilm and anti-infective properties. ${ }^{4}$

Thus, the synthesis of highly substituted pyridine derivatives has attracted much attension, and a number of methods have been developed to prepare these compounds using a variety of protocols. Those

\footnotetext{
*For correspondence
}

include Vilsmeier reactions of tertiary alcohols, ${ }^{5}$ Diels-Alder reactions of 3-siloxy-1-aza-1,3-butadienes and 6-alkyl-3,5-dichloro- $2 H$-1,4-oxazin-2ones with different types of acetylenic compounds, ${ }^{6}$ $\mathrm{Ni} / \mathrm{Ru}$-catalysed cycloadditions of alkynes and nitriles, ${ }^{7}[4+2]$ cycloadditions of oximinosulfonates, ${ }^{8}$ reaction of imines with enamines or carbonyl compounds, ${ }^{9}$ condensation of $\alpha, \beta$-unsaturated esters or nitriles with thiols, ${ }^{10}$ and transformation of ketene dithioacetals to pyridine derivatives. ${ }^{11}$

A few MCR methods are also reported for synthesis of diverse substituted pyridines, such as three-component condensations of aldehyde, malononitrile and thiol using various bases $\mathrm{Et}_{3} \mathrm{~N}, \mathrm{DABCO}^{12}$ and basic ionic liquid $[\mathrm{bmIm}] \mathrm{OH},{ }^{13}$ and microwave irradiation of aldehyde, $\beta$-ketoester and ammonium nitrate using bentonite clay. ${ }^{14}$ One-pot, three-component condensation of aldehydes, $O$-picolylamines and isocyanides produced the $1 \mathrm{H}$-imidazol-4-yl-pyridines in the presence of Lewis acid in methanol. ${ }^{15}$ Recently Zhu et al reported the one-pot MCRs of aromatic aldehydes, 3-cyanoacetyl indoles and ammonium acetate under microwave irradiation in the synthesis of bis ( $3^{\prime}$-indolyl)pyridine derivatives. ${ }^{16}$

Nanocrystalline metal oxides have found excellent applications as active adsorbents for gases, for destruction of hazardous chemicals ${ }^{17}$ and as catalysts for various organic transformations. ${ }^{18}$ Their high reactivity is due to high surface areas combined 
with unusually reactive morphologies. In continuation of our work on the application of nanomaterials in organic methodologies, here we report an effecttive three-component condensation of aldehydes, malononitrile and thiols to afford 2-amino-4-aryl3,5-dicyano-6-sulfanylpyridines $\mathbf{P}$ and the corresponding 1,4-dihydropyridines DP in moderate to high yields by using nanocrystalline magnesium oxide (NAP-MgO) catalyst (schemes 1 and 2).

\section{Experimental}

\subsection{General remarks}

Nanocrystalline $\mathrm{MgO}$ samples were obtained from NanoScale Materials Inc., (formally Nantek, Inc.) Manhattan, Kansas, USA. All catalysts were calcined at $400^{\circ} \mathrm{C}$ for $4 \mathrm{~h}$ before use. All chemicals were purchased from Aldrich Chemicals or S.D Fine Chemicals Pvt. Ltd. India, and used as received. ACME silica gel (60-120 mesh) was used for column chromatography, while thin layer chromatography was performed on Merck make precoated silica gel $60-\mathrm{F}_{254}$ plates. Melting points were measured in open capillary tubes and are uncorrected. The IR spectra of all compounds were recorded with a NEXUS 670 FTIR spectrometer (Necolet Corporation Ltd, USA) using $\mathrm{KBr}$ pellet method. The IR values are reported in reciprocal centimeters $\left(\mathrm{cm}^{-1}\right)$. The ${ }^{1} \mathrm{H},{ }^{13} \mathrm{C}$ NMR spectra were recorded in DMSO$d_{6}$ with a Varian-Gemini $200 \mathrm{MHz}$ or BrukerAvance $300 \mathrm{MHz}$ spectrometer. Chemical shifts $(\delta)$ are reported in parts per million (ppm), using TMS $(\delta=0)$ as an internal standard. The mass spectra were recorded with a QSTAR XL high resolution mass spectrometer (Applied Biosystems, Foster city, USA).

\subsection{Typical procedure for the synthesis of pyridines and 1,4-dihydropyridines}

To a stirred solution of the aldehyde $(1.0 \mathrm{mmol})$ and malononitrile $(2.1 \mathrm{mmol})$ in $5 \mathrm{ml}$ of ethanol, was added NAP-MgO $(0 \cdot 1 \mathrm{~g})$ at room temperature. The resulting mixture was heated to $50^{\circ} \mathrm{C}$, the thiol $(1.1 \mathrm{mmol})$ was added and the reaction mixture was refluxed. After completion of the reaction (monitored by TLC), the mixture was brought to room temperature, centrifuged to separate the catalyst and the catalyst was washed with ethyl acetate $(3 \times 5 \mathrm{~mL})$. The centrifugate was concentrated under reduced pressure to afford the crude product, which after chromatography on silica gel (60-120 mesh) using hexane/ethyl acetate in varying proportions as eluent afforded the respective pyridine or 1,4-dihydropyridine. The products were characterized on the basis of spectral data and the data of known products were also compared with the literature data. ${ }^{12,13}$ The physical and spectral data of the new products are given below.

2.2a 2-Amino-4-furan-2-yl-6-phenylsulfanyl-pyridine-3,5-dicarbonitrile (P9): Yellow solid; Melting point $190-192^{\circ} \mathrm{C}$; IR (KBr): $3410,3319,3215$, $2213,1626,1578,1538,1515,1477,1265,749$, $687 \mathrm{~cm}^{-1} ;{ }^{1} \mathrm{H}$ NMR (DMSO- $\left.d_{6}, 200 \mathrm{MHz}\right) \delta 6.71(t$, $J=3.8 \mathrm{~Hz}, 1 \mathrm{H}), 6.91(s, b r, 2 \mathrm{H}), 7.43-7.58(m, 6 \mathrm{H})$, $7.82(s, 1 \mathrm{H}),{ }^{13} \mathrm{C}$ NMR (DMSO- $\left.d_{6}, 75 \mathrm{MHz}\right) \delta 82.7$, $89.4,112 \cdot 8,115 \cdot 5,115 \cdot 6,116 \cdot 4,127 \cdot 1,129.4$, $129.6,134 \cdot 8,143.9,145 \cdot 0,146 \cdot 5,160 \cdot 2,167 \cdot 3$; Mass (ESI): $m / z 341(\mathrm{M}+\mathrm{Na})^{+}$; HRMS (ESI): Anal. Calcd. for $\mathrm{C}_{17} \mathrm{H}_{10} \mathrm{~N}_{4} \mathrm{ONaS}$ : 341.0473; Found: 341.0487 .

\section{$2.2 \mathrm{~b}$ 2-Amino-4-phenyl-6-para-tolylsulfanyl-pyri-} dine-3,5-dicarbonitrile (P10): Colourless solid; Melting point $246-249^{\circ} \mathrm{C}$; IR (KBr): 3450,3322 , $3208,2214,1618,1547,1524,1490,1264$, $808,704 \mathrm{~cm}^{-1} ;{ }^{1} \mathrm{H}$ NMR (DMSO- $\left.d_{6}, 200 \mathrm{MHz}\right) \delta$ $2.43(s, 3 \mathrm{H}), 6.58(s, b r, 2 \mathrm{H}), 7.24(d, J=8.2 \mathrm{~Hz}$, $2 \mathrm{H}), 7.43(d, J=8.2 \mathrm{~Hz}, 2 \mathrm{H}), 7.51-7.58(m, 5 \mathrm{H})$; ${ }^{13} \mathrm{C}$ NMR (DMSO- $\left.d_{6}, 75 \mathrm{MHz}\right) \delta 20 \cdot 8,86 \cdot 9,93 \cdot 1$, $114.9,115 \cdot 2,123.4,128 \cdot 3,128 \cdot 6,130 \cdot 0,130 \cdot 2$, $133.9,134 \cdot 8,139.5,158 \cdot 5,159 \cdot 6,166 \cdot 5$; Mass (ESI): $m / z 365(\mathrm{M}+\mathrm{Na})^{+}$; HRMS (ESI): Anal. Calcd. for $\mathrm{C}_{20} \mathrm{H}_{14} \mathrm{~N}_{4} \mathrm{NaS}$ : 365.0836; Found: 365.0848

2.2c 2-Amino-4-(4-methoxy-phenyl)-6-para-tolylsulfanyl-pyridine-3,5-dicarbonitrile (P11): Pale yellow solid; Melting point $230-233^{\circ} \mathrm{C}$; IR (KBr) v 3463 , $3323,3215,2221,1632,1603,1545,1508,1258$, $1179, \quad 1028,811 \mathrm{~cm}^{-1} ;{ }^{1} \mathrm{H}$ NMR (DMSO- $d_{6}$, $200 \mathrm{MHz}) \delta 2.38(s, 3 \mathrm{H}), 3.85(s, 3 \mathrm{H}), 6.74(s, b r$, $2 \mathrm{H}), 7.0(d, J=7.5 \mathrm{~Hz}, 2 \mathrm{H}), 7.19(d, J=8.2 \mathrm{~Hz}$, $2 \mathrm{H}), 7.37(d, J=7.5 \mathrm{~Hz}, 2 \mathrm{H}), 7.43(d, J=8.2 \mathrm{~Hz}$, $2 \mathrm{H}) ;{ }^{13} \mathrm{C}$ NMR (DMSO- $\left.d_{6}, 75 \mathrm{MHz}\right) \delta 20.9,55 \cdot 3$, $86 \cdot 8,93 \cdot 2,113 \cdot 8,114 \cdot 1,115 \cdot 3,115 \cdot 5,123 \cdot 5,125 \cdot 8$, $128 \cdot 1,130 \cdot 1,130 \cdot 2,131 \cdot 3,134 \cdot 9,139.5,158 \cdot 3$, 159.8, 160.8, 166.6; Mass (ESI): $m / z 395(\mathrm{M}+\mathrm{Na})^{+}$; HRMS (ESI): Anal. Calcd. for $\mathrm{C}_{21} \mathrm{H}_{16} \mathrm{~N}_{4} \mathrm{ONaS}$ : 395.0942; Found: 395.0944. 
2.2d 2-Amino-6-(furan-2-ylmethylsulfanyl)-4-(4methoxy-phenyl)-pyridine-3,5-dicarbonitrile (P15): Pale yellow solid; Melting point $217-218^{\circ} \mathrm{C}$; IR (KBr): 3459, 3324, 3209, 2363, 2214, 1616, 1541, $1506,1459,1247,1170,1016,826,743 \mathrm{~cm}^{-1} ;{ }^{1} \mathrm{H}$ NMR (DMSO- $\left.d_{6}, 200 \mathrm{MHz}\right) \delta 3.88(s, 3 \mathrm{H}), 4.51(s$, $2 \mathrm{H}), \quad 6.29 \quad(t, \quad J=2.2, \quad 2.9 \mathrm{~Hz}, \quad 1 \mathrm{H}), 6.44 \quad(d$, $J=2.9 \mathrm{~Hz}, 1 \mathrm{H}), 7.04(d, J=8.8 \mathrm{~Hz}, 2 \mathrm{H}), 7.37-7.62$ $(m, 5 \mathrm{H}) ;{ }^{13} \mathrm{C}$ NMR (DMSO- $\left.d_{6}, 75 \mathrm{MHz}\right) \delta 25.9$, $55 \cdot 2,85 \cdot 9,93 \cdot 4,108 \cdot 9,110 \cdot 7,113 \cdot 6,114 \cdot 0,115 \cdot 3$, $125 \cdot 7,130 \cdot 1,142 \cdot 7,149 \cdot 8,158 \cdot 1,159 \cdot 6,160 \cdot 7$, 165.4; Mass (ESI): $m / z 369(\mathrm{M}+\mathrm{Na})^{+}$; HRMS (ESI): Anal. Calcd. for $\mathrm{C}_{19} \mathrm{H}_{14} \mathrm{~N}_{4} \mathrm{ONaS}$ : 369.0786; Found: 369.0776.

2.2e 2-Amino-4-(2,6-dichloro-phenyl)-6-para-tolylsulfanyl-1,4-dihydro-pyridine-3,5-dicarbonitrile

(DP3): Colourless solid; Melting point 313$315^{\circ} \mathrm{C}$; IR (KBr): 3443, 3353, 2204, 2168, 1643, $1487,1246,1035,811,772 \mathrm{~cm}^{-1}$; ${ }^{1} \mathrm{H}$ NMR (DMSO$\left.d_{6}, 200 \mathrm{MHz}\right) \delta 2.38(s, 3 \mathrm{H}), 5.4(s, b r, 2 \mathrm{H}), 5.65(s$, $1 \mathrm{H}), 7.17-7.51(\mathrm{~m}, 7 \mathrm{H}), 8.57(\mathrm{~s}, b r, 1 \mathrm{H}) ;{ }^{13} \mathrm{C}$ NMR (DMSO- $\left.d_{6}, 75 \mathrm{MHz}\right) \delta 20 \cdot 6,34 \cdot 8,52 \cdot 1,86 \cdot 9,117 \cdot 4$, $119.7,125.5,128.6,130 \cdot 1,130.4,131.4,135 \cdot 1$, 138.8, 143.4, 151.4; Mass (ESI): $m / z 435(\mathrm{M}+\mathrm{Na})^{+}$; HRMS (ESI): Anal. Calcd. for $\mathrm{C}_{20} \mathrm{H}_{14} \mathrm{~N}_{4} \mathrm{NaSCl}_{2}$ : 435.0213; Found: 435.0226.

2.2f 2-Amino-4-(2-chloro-6-fluoro-phenyl)-6-paratolylsulfanyl-1,4-dihydro-pyridine-3,5-dicarbonitrile (DP6): Yellow solid; Melting point $277-279^{\circ} \mathrm{C}$; IR (KBr) v 3465, 3362, 2205, 2169, 1643, 1599, $1488,1449,1243,892,778 \mathrm{~cm}^{-1}$; ${ }^{1} \mathrm{H}$ NMR (DMSO$\left.d_{6}, 200 \mathrm{MHz}\right) \delta 2.36(s, 3 \mathrm{H}), 5.22(d, J=2.1 \mathrm{~Hz}$, $1 \mathrm{H}), 5.4(s, b r, 2 \mathrm{H}), 6.98-7.53(\mathrm{~m}, 7 \mathrm{H}), 8.65(\mathrm{~s}, \mathrm{br}$, $1 \mathrm{H}) ;{ }^{13} \mathrm{C}$ NMR (DMSO-d $\left.6,75 \mathrm{MHz}\right) \delta 20 \cdot 6,35 \cdot 5$, $52 \cdot 4,87 \cdot 4,115 \cdot 2,115 \cdot 5,117 \cdot 6,119 \cdot 9,126 \cdot 1,130 \cdot 4$, $130 \cdot 8,138.5,142.9,151 \cdot 1$; Mass (ESI): $m / z 419$ $(\mathrm{M}+\mathrm{Na})^{+}$; HRMS (ESI): Anal. Calcd. for $\mathrm{C}_{20} \mathrm{H}_{14}$ $\mathrm{N}_{4} \mathrm{FNaSCl}$ : 419.0509; Found: 419.0518.

\section{$2.2 \mathrm{~g}$ 2-Amino-4-(2,6-dimethoxy-phenyl)-6-para-} tolylsulfanyl-pyridine-3,5-dicarbonitrile (P17):

Colourless solid; Melting point $202-203^{\circ} \mathrm{C}$; IR (KBr) v 3440, 3343, 3220, 2212, 2180, 1630, 1593, $1541,1465,1253,1106,1021,768 \mathrm{~cm}^{-1} ;{ }^{1} \mathrm{H}$ NMR (DMSO- $\left.d_{6}, 200 \mathrm{MHz}\right) \delta 2.42(s, 3 \mathrm{H}), 3.85(s, 6 \mathrm{H})$, $6.62(s, b r, 2 \mathrm{H}), 6.7(d, J=8.8 \mathrm{~Hz}, 2 \mathrm{H}), 7.24(d$, $J=8 \cdot 1 \mathrm{~Hz}, 2 \mathrm{H}), 7.45(d, J=8 \cdot 1 \mathrm{~Hz}, 2 \mathrm{H}), 7.66(s$, $1 \mathrm{H}$ ); ${ }^{13} \mathrm{C}$ NMR (DMSO- $\left.d_{6}, 75 \mathrm{MHz}\right) \delta 20 \cdot 8,56 \cdot 0$, $88 \cdot 8,94 \cdot 8,104 \cdot 5,110 \cdot 8,114 \cdot 7,114 \cdot 9,123 \cdot 2,130 \cdot 0$,
$132 \cdot 2, \quad 135.0, \quad 139.5, \quad 153.9, \quad 156 \cdot 6,159.5,165 \cdot 8$; Mass (ESI): $m / z 425(\mathrm{M}+\mathrm{Na})^{+}$; HRMS (ESI): Anal. Calcd. for $\mathrm{C}_{22} \mathrm{H}_{18} \mathrm{~N}_{4} \mathrm{O}_{2} \mathrm{NaS}$ : 425.1048; Found: $425 \cdot 1037$.

\section{Results and discussion}

In order to understand the relationship between structure and reactivity, various forms of magnesium oxide crystals $\mathrm{CM}-\mathrm{MgO}$ (commercial $\mathrm{MgO}$, SSA: $30 \mathrm{~m}^{2} / \mathrm{g}$ ), NA- $\mathrm{MgO}$ (NanoActive $\mathrm{MgO}$, conventionally prepared $\mathrm{MgO}, \mathrm{SSA}: 250 \mathrm{~m}^{2} / \mathrm{g}$ ), NAP-MgO (NanoActive Plus $\mathrm{MgO}$, aerogel prepared $\mathrm{MgO}$, SSA: $590 \mathrm{~m}^{2} / \mathrm{g}$ ) were initially evaluated for the three-component condensation of benzaldehyde, malononitrile, and thiophenol at reflux temperature of ethanol. All these $\mathrm{MgO}$ crystals catalysed the reaction, but best result was obtained with NAP$\mathrm{MgO}$ (table 1).

In order to investigate the scope of the above optimized protocol, a variety of structurally different aldehydes with different thiols and malononitrile were employed for the three component condensation and the results are depicted in tables 2 and 3 . As summarized in table 2, for the synthesis of substituted pyridines, it was found that aromatic as well as heterocyclic aldehydes underwent this reaction to

Table 1. One-pot synthesis of 2-amino-4-phenyl-6phenylsulfanyl-pyridine-3,5-dicarbonitrile P1 with various catalysts ${ }^{\mathrm{a}}$

\begin{tabular}{llcc}
\hline Entry & \multicolumn{1}{c}{ Catalyst } & Time (h) & Yield (\%) \\
\hline 1 & NAP-MgO & $2,2^{\mathrm{c}}$ & $64,58^{\mathrm{c}}$ \\
2 & NA-MgO & 4 & 59 \\
3 & CM-MgO & 9 & 55 \\
4 & Sil-NAP-MgO & 4 & 50 \\
5 & None & 12 & - \\
\hline
\end{tabular}

${ }^{\mathrm{a}}$ Reaction conditions: Benzaldehyde (1.0 mmol), malononitrile $(2 \cdot 1 \mathrm{mmol})$, thiophenol $(1 \cdot 1 \mathrm{mmol})$, catalyst $(0 \cdot 1 \mathrm{~g})$, ethanol $(5 \mathrm{~mL})$ at reflux temperature

${ }^{\mathrm{b}}$ Isolated yield; ${ }^{\mathrm{c}}$ Fourth cycle

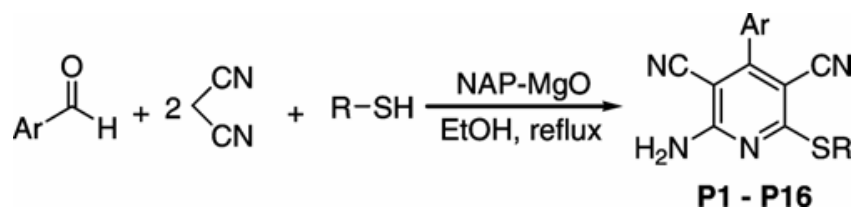

Scheme 1. One-pot synthesis of substituted pyridines catalysed by NAP-MgO. 
Table 2. One-pot synthesis of substituted pyridines catalysed by NAP-MgO'

\begin{tabular}{|c|c|c|c|c|c|}
\hline Entry & $\mathrm{Ar}$ & $\mathrm{R}$ & Time (h) & Product $\mathbf{P}^{\mathrm{b}}$ & Yield $(\%)^{c}$ \\
\hline 1. & $\mathrm{C}_{6} \mathrm{H}_{5}$ & $\mathrm{C}_{6} \mathrm{H}_{5}$ & 2 & P1 & 64 \\
\hline 2. & $4-\mathrm{MeO}-\mathrm{C}_{6} \mathrm{H}_{4}$ & $\mathrm{C}_{6} \mathrm{H}_{5}$ & 6 & P2 & 61 \\
\hline 3. & 4-Me- $\mathrm{C}_{6} \mathrm{H}_{4}$ & $\mathrm{C}_{6} \mathrm{H}_{5}$ & 6 & P3 & 59 \\
\hline 4. & $4-\mathrm{NO}_{2}-\mathrm{C}_{6} \mathrm{H}_{4}$ & $\mathrm{C}_{6} \mathrm{H}_{5}$ & 2 & P4 & 52 \\
\hline 5. & $4-\mathrm{Cl}-\mathrm{C}_{6} \mathrm{H}_{4}$ & $\mathrm{C}_{6} \mathrm{H}_{5}$ & 2 & P5 & 49 \\
\hline 6. & $4-\mathrm{OH}-\mathrm{C}_{6} \mathrm{H}_{4}$ & $\mathrm{C}_{6} \mathrm{H}_{5}$ & 7 & P6 & 64 \\
\hline 7. & $4-\mathrm{HOOC}-\mathrm{C}_{6} \mathrm{H}_{4}$ & $\mathrm{C}_{6} \mathrm{H}_{5}$ & 2 & P7 & 50 \\
\hline 8. & & $\mathrm{C}_{6} \mathrm{H}_{5}$ & 9 & P8 & 48 \\
\hline 9. & & $\mathrm{C}_{6} \mathrm{H}_{5}$ & 4 & P9 & 69 \\
\hline 10. & $\mathrm{C}_{6} \mathrm{H}_{5}$ & 4-Me- $\mathrm{C}_{6} \mathrm{H}_{4}$ & 4 & P10 & 65 \\
\hline 11. & 4-MeO- $\mathrm{C}_{6} \mathrm{H}_{4}$ & $4-\mathrm{Me}-\mathrm{C}_{6} \mathrm{H}_{4}$ & 8 & P11 & 59 \\
\hline 12. & $\mathrm{C}_{6} \mathrm{H}_{5}$ & $4-\mathrm{Cl}-\mathrm{C}_{6} \mathrm{H}_{4}$ & 5 & P12 & 50 \\
\hline 13. & $\mathrm{C}_{6} \mathrm{H}_{5}$ & $\mathrm{C}_{6} \mathrm{H}_{5}-\mathrm{CH}_{2}$ & 4 & P13 & 44 \\
\hline 14. & $4-\mathrm{Me}-\mathrm{C}_{6} \mathrm{H}_{4}$ & $\mathrm{C}_{6} \mathrm{H}_{5}-\mathrm{CH}_{2}$ & 7 & P14 & 41 \\
\hline 15. & 4-MeO- $\mathrm{C}_{6} \mathrm{H}_{4}$ & & 8 & P15 & 56 \\
\hline 16. & $4-\mathrm{Cl}-\mathrm{C}_{4} \mathrm{H}_{4}$ & & 6 & P16 & 52 \\
\hline
\end{tabular}

${ }^{a}$ Reaction conditions: Aldehyde $(1 \mathrm{mmol})$, malononitrile $(2.1 \mathrm{mmol})$, thiophenol $(1.1 \mathrm{mmol})$, $\mathrm{NAP}-\mathrm{MgO}(0 \cdot 1 \mathrm{~g})$, ethanol $(5 \mathrm{~mL})$ at reflux temperature

${ }^{\mathrm{b}}$ All the products were characterized by IR, ${ }^{1} \mathrm{H}-\mathrm{NMR},{ }^{13} \mathrm{C}-\mathrm{NMR}$ and mass spectroscopy ${ }^{\mathrm{c}}$ Isolated yield

Table 3. One-pot synthesis of substituted 1,4-dihydropyridines catalysed by NAP-MgOa .

\begin{tabular}{cccccc}
\hline Entry & \multicolumn{1}{c}{$\mathrm{Ar}$} & $\mathrm{R}$ & Time (h) & Product DP $^{\mathrm{b}}$ & Yield (\%) $^{\mathrm{c}}$ \\
\hline 1. & $2,6-\mathrm{Cl}-\mathrm{C}_{6} \mathrm{H}_{3}$ & $\mathrm{C}_{6} \mathrm{H}_{5}$ & 5 & DP1 & 87 \\
2. & $2,6-\mathrm{Cl}-\mathrm{C}_{6} \mathrm{H}_{3}$ & $4-\mathrm{Cl}_{3}-\mathrm{C}_{6} \mathrm{H}_{4}$ & 4 & $\mathbf{D P 2}$ & 80 \\
3. & $2,6-\mathrm{Cl}-\mathrm{C}_{6} \mathrm{H}_{3}$ & $4-\mathrm{Me}-\mathrm{C}_{6} \mathrm{H}_{4}$ & 4 & $\mathbf{D P 3}$ & 84 \\
& & & 3 & $\mathbf{D P 4}$ & 71 \\
4. & $2,6-\mathrm{Cl}-\mathrm{C}_{6} \mathrm{H}_{3}$ & & & & \\
5. & $2-\mathrm{Cl}-6-\mathrm{F}-\mathrm{C}_{6} \mathrm{H}_{3}$ & $\mathrm{C}_{6} \mathrm{H}_{5}$ & 2 & $\mathbf{D P 5}$ & 69 \\
6. & $2-\mathrm{Cl}-6-\mathrm{F}-\mathrm{C}_{6} \mathrm{H}_{3}$ & $4-\mathrm{Me}-\mathrm{C}_{6} \mathrm{H}_{4}$ & 2 & DP5 & 85 \\
\hline
\end{tabular}

a Reaction conditions: Aldehyde $(1 \mathrm{mmol})$, malononitrile $(2 \cdot 1 \mathrm{mmol})$, thiophenol $(1.1 \mathrm{mmol})$, $\mathrm{NAP}-\mathrm{MgO}(0 \cdot 1 \mathrm{~g})$, ethanol $(5 \mathrm{~mL})$ at reflux temperature

${ }^{\mathrm{b}}$ All the products were characterized by IR, ${ }^{1} \mathrm{H}-\mathrm{NMR},{ }^{13} \mathrm{C}-\mathrm{NMR}$ and mass spectroscopy ${ }^{\mathrm{c}}$ Isolated yield

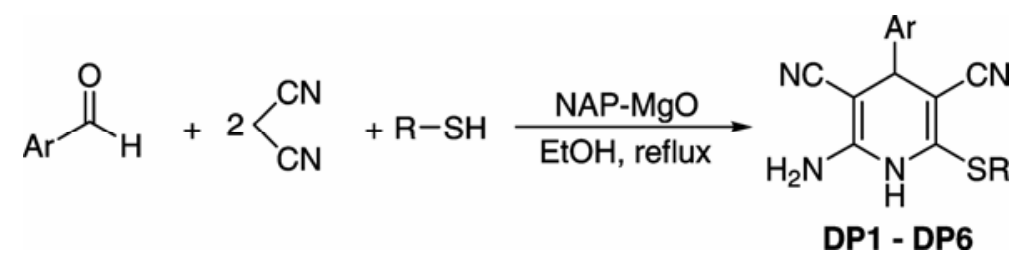

Scheme 2. One-pot synthesis of substituted 1,4-dihydropyridines catalysed by NAP-MgO. 


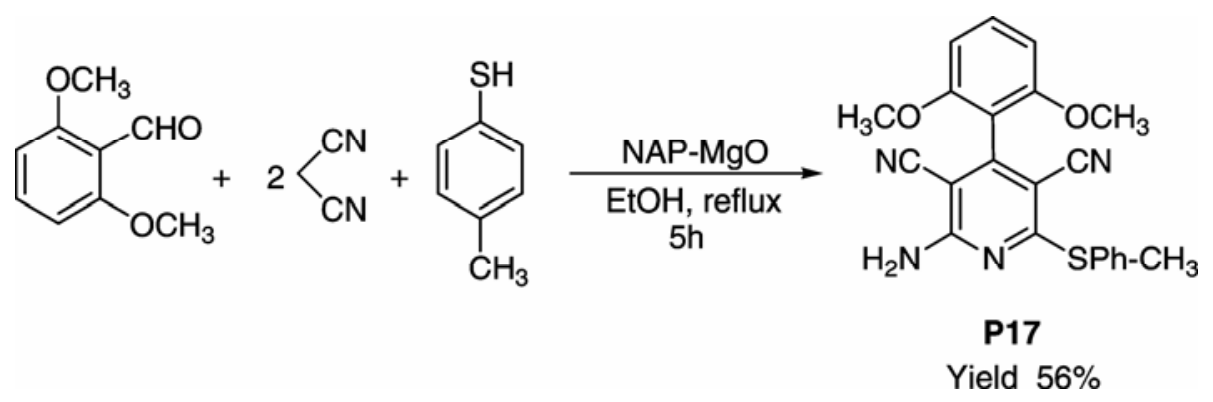

Scheme 3. One-pot synthesis of substituted pyridine P17 catalysed by NAP$\mathrm{MgO}$.

afford their corresponding pyridine products in moderate yields. The substrates bearing electrondonating (methyl, methoxy, methylenedioxy, hydroxy) or electron-withdrawing (nitro, carboxy, chloro) groups on the aromatic ring showed similar results. Using furfural, malononitrile and thiophenol the pyridine derivative P9 (table 2, entry 9) was obtained in good yield. In contrast to the findings of Evdokimov et al, ${ }^{12}$ with aliphatic aldehydes, unidentified constituents were isolated instead of the pyridine product. ${ }^{13}$ Whereas, aliphatic cyclohexanethiol with 4-chlorobenzaldehyde gave the corresponding pyridine P16 (table 2, entry 16) in 52\% of isolated yield. The other thiols such as 4-methyl benzene thiol, 4-chloro benzene thiol and furyl methanethiol reacted with different aromatic aldehydes to afford their corresponding pyridine derivatives in good yields (table 2, entries 10-12 and 15), and with benzylthiol afforded the pyridine product in moderate yields (table 2, entries 13 and 14).

When $o, o^{\prime}$-disubstituted aldehydes were used in this process, 1,4-dihydropyridines were obtained in high yields (table 3 ). The difference in the product profile may be due to steric hinderance of $o, o^{\prime}$ disubstituted biaryl systems. ${ }^{12,13}$ In this system, 2,6dichloro-benzaldehyde and 2-Cl,6-F-benzaldehyde was combined with various thiols to afford 1,4dihydropyridines DP1-DP6 in good to high yields. In contrast, 2,6-dimethoxy benzaldehyde gave the substituted pyridine P17 instead of the predicted 1,4dihydropyridine (scheme 3). This may be due to the difference in the electronic and steric properties of 2,6-dimethoxy benzaldehyde compared to 2,6-dihalo aldehydes and also the possibility of hydrogen bonding between halogens of 2,6-dihalo aldehydes and hydrogen of pyridine ring.

We also explored different active methylene group containing nitriles such as ethyl cyanoacetate and 2phenyl acetonitrile for the synthesis of pyridines.
When the reaction was conducted with ethyl cyanoacetate, benzaldehyde and thiophenol, only $6 \%$ of the pyridine derivative was isolated. However, there was no reaction with phenyl acetonitrile.

It is noteworthy that there was no reaction without $\mathrm{NAP}-\mathrm{MgO}$ catalyst (table 1 , entry 5), which indicated that the catalyst is essential for the reaction. The proposed mechanism is, in the first step of this reaction, malononitrile is activated by $\mathrm{O}^{2-} / \mathrm{O}^{-}$(Lewis base) and aldehyde is activated by $\mathrm{Mg}^{2+} / \mathrm{Mg}^{+}$(Lewis acid) of NAP- $\mathrm{MgO}$. This involves the Knoevenagel reaction which forms the corresponding Knoevenagel product I (scheme 4). The second molecule of malononitrile then undergoes Michael addition to $\mathbf{I}$, simultaneously thiol activation by $\mathrm{Mg}^{2+} / \mathrm{Mg}^{+}$of $\mathrm{NAP}-\mathrm{MgO}$, and the thiolate addition to $\mathrm{CN}$ of the adduct. Then cyclization takes place to form 1,4dihydropyridine, which upon aromatization and aerobic oxidation under the reaction conditions, leads to pyridine product. ${ }^{13}$ Presumably, the reactions of $o, o^{\prime}$-dihalo substituted aldehydes were restricted to 1,4-dihydropyridines only, as further aromatization did not occur, possibly, this is due to steric hinderance at the 4-position by two ortho substituents at the aromatic ring. ${ }^{12,13}$

To understand the relationship between structure and reactivity of the catalyst in this three-component reaction, it is important to know the structure and nature of the reactive sites of $\mathrm{NAP}-\mathrm{MgO}$. The catalyst NAP-MgO has a single crystallite, threedimensional polyhedral structure, with high surface concentrations of edges/corners and various exposed crystal planes (such as 002, 001, 111). This leads to inherently high surface reactivity per unit area. Besides this, the NAP-MgO has Lewis acid sites $\mathrm{Mg}^{2+}$, Lewis basic sites $\mathrm{O}^{2-}$ and $\mathrm{O}^{-}$, lattice-bound and isolated Bronsted hydroxyls and anionic and cationic vacancies. ${ }^{19}$ Thus, NAP- $\mathrm{MgO}$ displays the highest activity compared to $\mathrm{NA}-\mathrm{MgO}$ and $\mathrm{CM}-$ 

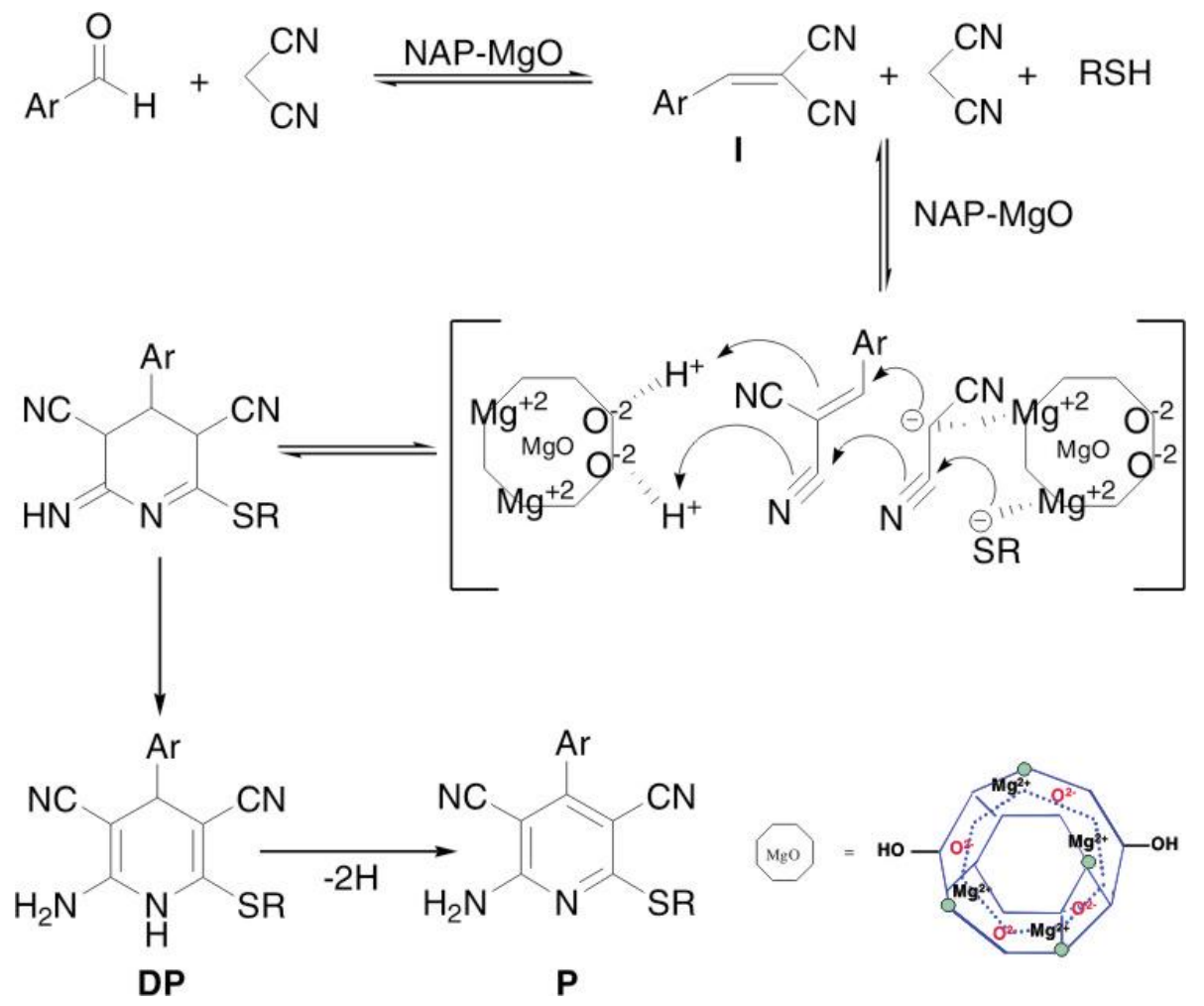

Scheme 4. The plausible mechanism for one-pot synthesis of substituted pyridines $\mathbf{P}$ and dihydropyridines DP catalysed by NAP-MgO.

$\mathrm{MgO}$. Generally, this three-component reaction is known to be driven by base catalysts, ${ }^{12}$ and accordingly, the surface $-\mathrm{OH}$ and $\mathrm{O}^{2-}$ sites of these oxide crystals are expected to trigger these reactions. The poorer result with the Sil-NAP- $\mathrm{MgO}^{19}$ devoid of free $-\mathrm{OH}$, was established the role of $-\mathrm{OH}$ (table 1 , entry 4). Although both $\mathrm{NAP}-\mathrm{MgO}$ and $\mathrm{NA}-\mathrm{MgO}$ possess defined shapes and the same average concentrations of surface $-\mathrm{OH}$ groups, a possible rationale for this higher reactivity towards pyridines by the NAP- $\mathrm{MgO}$ is that the presence of more surface Lewis acid sites (20\%), along with $-\mathrm{OH}$ groups present on the edge and corner sites on the NAP$\mathrm{MgO}$, which are stretched in three-dimensional space, are therefore more isolated and accessible to the reactants. Thus, NAP-MgO displays highest activity compared to $\mathrm{NA}-\mathrm{MgO}$ and $\mathrm{CM}-\mathrm{MgO}$. This three-component reaction proceeds via dual activation of substrates by NAP-MgO. The Lewis base moiety $\left(\mathrm{O}^{2-} / \mathrm{O}^{-}\right)$of the catalyst activates the malononitrile and the Lewis acid moiety $\left(\mathrm{Mg}^{2+} / \mathrm{Mg}^{+}\right)$ activates the aldehyde and thiol (scheme 4). ${ }^{20}$

The NAP-MgO was reused for four cycles with consistent activity (table 1, entry 1). After completion of the reaction, the catalyst was centrifuged and washed with ethyl acetate for three times. The recovered catalyst was activated at $250^{\circ} \mathrm{C}$ for $1 \mathrm{~h}$ under nitrogen atmosphere, before reuse.

\section{Conclusion}

In conclusion, we have demonstrated that nanocrystalline $\mathrm{MgO}$ is an effective catalyst for the MCRs of structurally diverse aldehydes with various thiols and malononitrile, resulting in the formation of substituted pyridines and 1,4-dihydropyridines in moderate to high yields. The catalyst can be recovered, and reused atleast up to four cycles for the synthesis of pyridine derivatives.

\section{Acknowledgements}

K M thanks Council of Scientific and Industrial Research (CSIR), New Delhi, India for the award of his Senior Research Fellowship.

\section{References}

1. Hantzsch A 1882 Justus Liebigs Ann. Chem. 215 1; Bossert F and Vater W 1989 Med. Res. Rev. 9291 
2. Boger D L and Nakahara S 1991 J. Org. Chem. 56 880; Boger D L and Kasper A M $1989 \mathrm{~J}$. Am. Chem. Soc. 111 1517; Zhang T Y, Stout J R, Keay J G, Scriven E F V, Toomey J E and Goe G L 1995 Tetrathedron 51 13177; Ma X and Gang D R 2004 Nat. Prod. Rep. 21752

3. Beukers $\mathrm{M} \mathrm{W}$, Chang $\mathrm{L} \mathrm{C} \mathrm{W}$, von Frijtag Drabbe Kunzel J K, Mulder-Krieger T, Spanjersberg R F, Brussee J and Ijzerman A P $2004 \mathrm{~J}$. Med. Chem. 47 3707; Chang L C W, von Frijtag Drabbe Kunzel J K, Mulder-Krieger T, Spanjersberg R F, Roerink S F, van den Hout $G$, Beukers $M$ W, Brussee $J$ and Ijzerman A P $2005 \mathrm{~J}$. Med. Chem. 48 2045; Reddy T R K, Mutter R, Heal W, Guo K, Gillet V J, Pratt S and Chen B $2006 \mathrm{~J}$. Med. Chem. 49 607; Fredholm B B, Ijzerman A P, Jacobson K A, Klotz K N and Linden J 2001 Pharmacol. Rev. 53 527; Perrier V, Wallace A C, Kaneko K, Safar J, Prusiner S B and Cohen F E 2000 Proc. Natl. Acad. Sci. USA 97 6073

4. Harada H, Watanuki S, Takuwa T, Kawaguchi K, Okazaki T, Hirano Y and Saitoh C 2002 PCT Int. Appl. WO 2002006237 Al 20020124; Levy S B, Alekshun M N, Podlogar B L, Ohemeng K, Verma A K, Warchol T, Bhatia B, Bowser T and Grier M 2005 US Pat. Appl. Pub. US 2005124678 Al 20050609

5. Thomas A D and Asokan C V 2001 J. Chem. Soc., Perkin Trans. 1, 2583; Thomas A D and Asokan C V 2002 Tetrahedron Lett. 432273

6. Fletcher M D, Hurst T E, Miles T J and Moody J 2006 Tetrathedron 62 5454; Meerpoel L, Deroover G, Aken K V, Lux G and Hoornaert G 1991 Synthesis 765

7. McCormick M M, Duong H A, Zuo G and Louie J $2005 \mathrm{~J}$. Am. Chem. Soc. 127 5030; Varela J A, Castedo L and Saa C 2003 J. Org. Chem. 688595

8. Renslo A R and Danheiser R L 1998 J. Org. Chem. 63 7840; Mashraqui S H and Karnik M A 1998 Tetrahedron Lett. 394895

9. Komatsu M, Ohgishi H, Takamatsu S, Ohshiro Y and Agawa T 1982 Angew. Chem. Int. Ed. 21 213; Vijin R J, Arts H J, Green R and Castelijns A M 1994 Synthesis 573

10. Kambe S and Saito K 1981 Synthesis 531; Kambe S, Saito K, Kishi H, Hayashi T and Sakurai A 1977 Synthesis 839

11. Anabha E R, Nirmala K N, Thomas A and Asokan C V 2007 Synthesis 428; Anabha E R and Asokan C V 2006 Synthesis 151

12. Evdokimov N M, Magedov I V, Kireev A S and Kornienko A 2006 Org. Lett. 8899
13. Ranu B C, Jana R and Sowmiah S 2007 J. Org. Chem. 723152

14. Penieres G, Garcia O, Franco K, Hernandez O and Alvarez C 1996 Heterocycl. Commun. 2 359; Cotterill I C, Usyatinsky A Y, Arnold J M, Clark D S, Dordick J S, Michels P C and Khmelnitsky Y L 1998 Tetrahedron. 391117

15. Illgen $\mathrm{K}$, Nerdinger $\mathrm{S}$, Behnke $\mathrm{D}$ and Friedrich $\mathrm{C}$ 2005 Org. Lett. 739

16. Zhu S L, Ji S J, Su X M, Sun C and Liu Y 2008 Tetrahedron Lett. 491777

17. Lucas E, Decker S, Khaleel A, Seitz A, Fultz S, Ponce A, Li W, Carnes C and Klabunde K J 2001 Chem. Eur. J. 7 2505; Schlogl R and Abd Hamid S B 2004 Angew. Chem. Int. Ed., 43 1628; Bell A T 2003 Science 299 1688; Carnes C L and Klabunde K J 2000 Langmuir 16 3764; Klabunde K J and Mulukutla R S 2001 Nanoscale materials in chemistry (New York: Wiley Interscience) Chapter 7, p. 223

18. Choudary B M, Kantam M L, Ranganath K V S, Mahendar K and Sreedhar B $2004 \mathrm{~J}$. Am. Chem. Soc. 126 3396; Choudary B M, Ranganath K V S, Pal U, Kantam M L and Sreedhar B $2005 \mathrm{~J}$. Am. Chem. Soc. 127 13167; Choudary B M, Ranganath K V S, Yadav J and Kantam M L 2005 Tetrahedron Lett. 46 1369; Choudary B M, Mahendar K and Ranganath K V S 2005 J. Mol. Catal. A: Chem. 234 25; Choudary B M, Mahendar K, Kantam M L, Ranganath K V S and Athar T 2006 Adv. Synth. Catal. 348 1977; Kantam M L, Ranganath K V S, Mahendar K, Chakrapani L and Choudary B M 2007 Tetrahedron Lett. 48 7646; Kantam M L, Mahendar K, Sreedhar B and Choudary B M 2008 Tetrahedron 64 3351; Kantam M L, Mahendar K, Sreedhar B, Vijay Kumar K and Choudary B M 2008 Synth. Commun. 383919

19. Jeevanandam P and Klabunde K J 2002 Langmuir 18 5309; Richards R, Li W, Decker S, Davidson C, Koper O, Zaikovski V, Volodin A, Rieker T and Klabunde K J $2000 \mathrm{~J}$. Am. Chem. Soc. 122 4921; Utamapanya S, Klabunde K J and Schlup J R 1991 Chem. Mater. 3 175; Klabunde K J, Stark J, Koper O, Mohs C, Park D G, Decker S, Jiang Y, Lagadic I and Zhang D 1996 J. Phys. Chem. 100 12142; Choudary B M, Mulukutla R S and Klabunde K J $2003 \mathrm{~J}$. Am. Chem. Soc. 1252020

20. Shibasaki M, Kanai M and Funabashi K $2002 \mathrm{~J}$. Chem. Soc. Chem. Commun. 1989; Qin B, Liu X, Shi J, Zheng K, Zhao H and Feng X 2007 J. Org. Chem. 72 2374; Mita T, Sasaki K, Kanai M and Shibasaki M $2005 \mathrm{~J}$. Am. Chem. Soc. 127 514; Shibasaki M and Kanai M 2001 Chem. Pharm. Bull. 49511 